This is an Accepted Manuscript of an article published by Taylor \& Francis in Journal of Contemporary Religion on 20/12/2015, available online: http://www.tandfonline.com/doi/full/10.1080/13537903.2016.1112646

\title{
A Lateral Reading of Religion: Christianity in Sister Relationships Sonya Sharma
}

\begin{abstract}
Sociologists of religion continue to give precedence to parent-child transmission in studies on religion and family. In doing so, other kinds of family relationships that also influence religious beliefs and practices remain in the background. In this article, instead of using a vertical lens, religion in the family is approached through a lateral reading of sisters' religious lives. Drawing on 13 biographical accounts, which included family diagrams and time-lines, conducted with adult women who identified as sisters and as Christian, this article examines the intersection of religion with practices of intimacy and social context. By looking laterally, this article explores the mutual shaping of religion and sibling ties and gives recommendations for the way this under-researched area can expand the sociological study of religion within families.
\end{abstract}

\section{Introduction}

The purpose of this article is to build on studies of lateral relations by examining how sibling ties are important to sociological knowledge on religion within families. I begin by surveying the relevant literature before outlining my study. The body of the article explores the intersections of religion, intimacy, and social context in sister relationships. I do this by examining three of 13 women's accounts. I argue that reading religion laterally is often overlooked because of the focus given to parent-child relationships in the sociological study of religion. This research offers another site through which to understand the formation of religious selves and how social worlds, shaped by sibling ties, can make such selves possible. In conclusion, I outline areas where further research on religion and lateral ties might be most productive.

\section{Religion and Family}

The relationship between religion and family is both historical and reciprocal (Pankhurst and Houseknecht). Family and religion are intertwined, affecting identities, relations, and everyday practices (Ammerman and Roof; Edgell) and sociologists of religion argue that family, particularly parents, are vital to religious socialisation. In sociological studies on religion and family, the parent-child relationship is normally the focus; for example, in recent empirical research, parents were seen as the most significant influence on children's religious lives among second-generation Asian Americans (Park and Ecklund) and Sokai Gakkai in Japan (Yūri). David Voas and Ingrid Storm found that, in England and Australia, two churchgoing parents have greater religious effect on their children than one church-going parent alone and that grandparents' religiosity also has an influence. Atheist and agnostic parents are not precluded from facilitating forms of religious participation among their children. Elaine Ecklund and Kristen Schultz (73) discovered that such parents do so in "a desire for a moral community" or because of their "spouse's beliefs". Parental breakup has also been observed to affect young people's religious lives (Denton), causing some eventually to disaffiliate or actively to affirm their faith. The primary relationship between parent and child is considered by many sociologists as pivotal to the ways in which religious beliefs and values persist in some form over the life course (e.g. Bengston; Crockett and Voas). Continued attention to vertical ties between parents and children as key to religious flourishing, survival, and decline can, however, discount other kinds of relationships within families that can affect individuals' 
relationship to religion. Sociologists have shown the impact that lateral ties between siblings (i.e. biological, adopted, step, chosen) can have on shaping identity and value formation (Mauthner, "Distant", Sistering; Mitchell, Siblings, Siblings). Yet, there is limited knowledge on how siblings affect the way religion is enacted, supported or abandoned in families, even though siblings typically spend more time with each other than they do with their parents and sibling relationships typically last longer. In the following section, I address three areas: a) the importance of sibling relations, and research on sisters, as emphasised by psychologists and sociologists, b) two examples of empirical research conducted on siblings, and c) studies that have begun to open up the examination of religion in sibling relations.

\section{Sibling Relations}

There has been an array of psychological and sociological research on sibling relationships (e.g. Connidis and Campbell; Dunn; Sanders), including studies on adult brothers and sisters. For example, Victor Cicirelli conducted cross-cultural research on sibling relationships, examining their differences in industrialised and non-industrialised societies. Sara Matthews studied the effects of parent care on sibling relationships, Ingred Amet Connidis examined how siblings negotiate the socio-economic inequality between them, and recent work by William Cornell explained the impact of sibling loss. Rosalind Edwards et al. (5) argue that, given the emphasis on the individual in late modernity anda preoccupation with individualisation in intimate relationships (Giddens), a distinctive feature of sibling relationships is "their seriality; that is the ability to be in a series of more than one, interconnected, in a sibling group, while at the same time remaining aware of uniqueness". Juliet Mitchell, who takes a feminist and psychoanalytical approach to studying siblings, contends that siblings feature prominently in relational and identity formation and often play a powerful role in the development of gender roles, sexuality, and experiences of violence. She makes a plea that

we make space for an analytical understanding of lateral relations along a horizontal axis, not instead of but in addition to the vertical, whose perspective is almost synonymous with so many of our disciplines. (Mitchell, "Siblings" 14)

Reading religion in sibling relationships means social explorations of personal biographies that include dynamics of verticality and power relations. Similarly, Melanie Mauthner, who has researched sisters, contends that sisters have largely been invisible in social science research because of their entrenchment in the ordinariness of everyday life, the privileging of "hierarchical and/or vertical forms of social life, such as marriage and parenting", and the "focus on oppressive ties related to inequalities of gender, race, age and class" rather than "reciprocal intimate ties" ("Distant" 636-7). Mauthner ("Distant" 627) notes that research on brothers is also undervalued, but notions of 'brotherhood' and 'fraternities' are much more prevalent in social and political contexts, including religious ones, than sisterhood or 'sistering.' She offers examples of the army, pubs, trade unions, sport, and academia where "men organize and bond" through structures of patriarchy (ibid). The Anglican and Catholic churches among other denominations and religious traditions can also be seen in this light. Research on Christian nuns, as sisterly religious communities, are exceptions (e.g. McNamara; Reed). But, as Mauthner states, "public patriarchies and masculinities are in marked contrast to the private femininities of sistering" (ibid). Focusing on sisters and religion contributes to existing literature on gender and religion (e.g. Aune, Sharma and Vincett). In examining sibling relationships, I draw on Lynn Jamieson's assertion that relationship research is important because of what it can reveal about social change ("Intimacy"). Recent empirical study on adult siblings highlights this. Within the context of China, Qian Forrest Zhang examined how adult siblings of two generations in one family were more influential and effective in generating status attainment than parents. His research 
demonstrates how siblings' social networks in one generation helped to facilitate social mobility, but how this lessened in the next generation because of economic changes and political policies. Zhang's research is important because it shows how the 'micro-level processes' of sibling relationships can reflect wider social transformations. He therefore suggests a move towards 'kin networks' as 'our analytic unit' as they may 'go far beyond simply being a source of support, but may in fact shape one's motivations in life" (90). The micro-level processes between siblings that Zhang refers to are evident in Suad Joseph's (50) study of Arab brother-sister relationships, which, she argues, have "been overlooked, romanticised, or seen as an extension of the patriarchal father/daughter relationship". Her study, based in Lebanon, exposed how Arab brothers and sisters inform each other's masculine and feminine identities through love and nurturance, power and violence. Joseph $(52,55)$ reveals the juncture of "psychodynamic, social structural, and cultural processes through which the brother/sister relationship contributes to the reproduction of Arab patriarchy", which is heterogeneously based on "state, class, religion, ethnic, rural/urban, and other differences". She uncovers the mutual shaping between intimate sibling relations and family and social processes.

Other research is beginning to note the importance of siblings to religious formation and practices and as broader societal responses to religion. For example, among Turkish Muslim university students, it was found that siblings were "important religious socialization agents whom the participants generally perceive as partners in religious activities" (Ozdikmenli-Demir and Şahin-Kütük 363). In his American study, Layton Field suggests that there is a"positive relationship between sibling communication and religiosity", meaning that, "ascommunication increases among siblings, religiosity also has the capacity to increase" (56). Further, Miri Song (282) investigated mixed siblings' perceptions of their racial, ethnic, and religious differences within their families. Her research demonstrates the 'ChristianMuslim boundary' that can exist in families. She describes a family in which one sibling, Myriam,"was seen as having chosen to be Muslim and Pakistani (as opposed to a neutral, hybrid stance)", which not only "impacted upon family relationships", but was also perceived as "a (problematic) symbolic assertion of difference within mainstream British society" (282). Song's research discloses how reading sibling relationships can shed light on wider social shifts in attitudes towards race and religion.

\section{The Study}

This article draws on data collected for a study on the way sister relationships affect religious commitments and identities and in turn how religion, specifically Christianity, shapes practices of intimacy between sisters. A sample of 13 adult women who identified as sisters and as Christian were recruited through known informants (i.e. a local minister and church members) and snowball sampling. The women were mainly white and middle class and attended Anglican congregations in Britain. Christianity was investigated because of Britain's cultural and historical relationship to Christianity and its status as Britain's majority religious tradition (Office for National Statistics). Christianity has also been affected by processes of secularisation and I was keen to understand how sister ties reflected this.

The ages of the participants in this study spread across generations, with the youngest being 25 and the oldest 75 years old. Focusing on these ages picks up on Lynn White's (555) contention that, apart from childhood and old age, little is known about sibling relationships in middle-aged adulthood. Glenna Spitze and Katherine Trent (977) concur: "Adult sibling ties are among the least studied of kin relations" and, as White (555) further states, they are "unique in their durability". This study aims to address a lacuna in relation to religion on sibling relations in the study of religion and family. 
The study used qualitative interview methods. Individual interviews were conducted, using a biographical method that "denotes research which utilises individual stories or other personal documents to understand lives within a social, psychological and/or historical frame" (Merrill and West 10). The interviews were typically "open and in-depth, using only a general guide to enable participants to explore their worlds" (ibid 119). Employing this approach assisted in capturing 'religion as lived'- "how religion and spirituality are practiced, experienced and expressed by ordinary people (rather than official spokespersons) in the context of their everyday lives" (McGuire 15, 12). Using a biographical method enabled attunement to the ways the women described and understood their religious practices and the circumstances in which they occurred and how these were often not only about themselves but also about others (Orsi 172): "[Lived] religion is situated amid the ordinary concerns of life, at the junctures of self and culture, family and social world ...religion is always religion-in-action, religion-in-relationships between people" (ibid). This methodological approach enabled me "to discern patterns but also distinctiveness in lives, the relationship between the particular and general, uniqueness and commonality" (Merrill and West 2). The women's biographical accounts revealed the intersection of religion, lateral relations, and social context.

The interviews included two elements. Firstly, a general set of open-ended questions that aimed to capture the women's biographies about religion, family, and sister relations over the life course. The questions also explored how and whether the sisters were 'close' to each other. Jamieson defines 'intimacy' as

... the quality of close connection between people and the process of building this quality. Although there may be no universal definition, intimate relationships are a type of personal relationships that are subjectively experienced and may also be socially recognised as close. The quality of 'closeness' that is indicated by intimacy can be emotional and cognitive, with subjective experiences including a feeling of mutual love, being 'of like mind' and special to each other. Closeness may also be physical, bodily intimacy, although an intimate relationship need not be sexual and both bodily and sexual contact can occur without intimacy. (Jamieson, "Intimacy" 1)

Jamieson conceptualises 'practices of intimacy', which builds on David Morgan's theorisation of 'family practices' (Family, Rethinking) - what people "do to create an experience of particular places, relationships and events as meaning and expressing family" (Jamieson, "Intimacy" 1). Practices of intimacy, which complement family practices, are "practices which enable, generate and sustain a subjective sense of closeness and being attuned and special to each other" (ibid). In this research I was interested in the way the women's closeness enabled and restricted discussions about religion, along with religious practice and exploration, and also in the way their religion constrained and strengthened forms of closeness between them. Individual interviews with sisters as opposed to interviews with sets of sisters were conducted because of ethical reasons related to possible discomfort or conflict as a result of disclosing sensitive information in the presence of one another (Mauthner, Sistering). A biographical method can potentially be (experienced as) intrusive and provoke difficult/unpleasant emotions in the interviewee. The implications for the findings are that discussion and dynamics between sisters were not observed. Sensitive aspects were dealt with by taking moments to ask how the women were feeling as the interviews progressed. In order to protect the women's identities and their privacy, all participants were given pseudonyms. Interviews took place in a cafe or the women's home or work place and lasted up to two hours. The interviews took place between 2012 and 2014.

The second element was drawing a family diagram and time-line; this element was introduced after a sense of rapport had been established with the interviewees. The diagram and time-line aimed to bring to light what often cannot be brought about by questions alone 
(Gabb 43-4). As the women drew these, they were asked to elaborate about family relations and events. The family diagram offered a visual chart of the women's families and a way to map the familial history and presence (or lack thereof) of religion and the women's religious socialisation through lateral relationships (and vertical ones). The time-line assisted in tracing chronological moments by which religion and the women's relationships with their sisters were more or less prominent (Mauthner, Sistering 189). It was also a visual tool to aid understanding the women's biographies over the life course. These demonstrated "that siblings are permanent but flexible members" whose roles were renegotiated in the light of various transitions, "changing circumstances and competing obligations" (White 557). The time-lines were another way to capture 'religion as lived'. As an example, I include Jess's timeline which showed "religion in action, religion in relationships" (Orsi 172).

Jess (age 38) was the eldest of two sisters who had been brought up in a non-religious household. She was introduced to Christianity by a church-going aunt and was the first to become a Christian in her immediate family. As the eldest she experienced rivalry with her younger sister, but because of her Christian faith, Jess decided to "build a relationship"with her sister and to "love" her sister in "new ways". This emerged after realising how much she missed her sister while spending one Christmas apart. Jess's time-line conveyed various 'lived' moments of religion in relation to her sister, which included the Christian

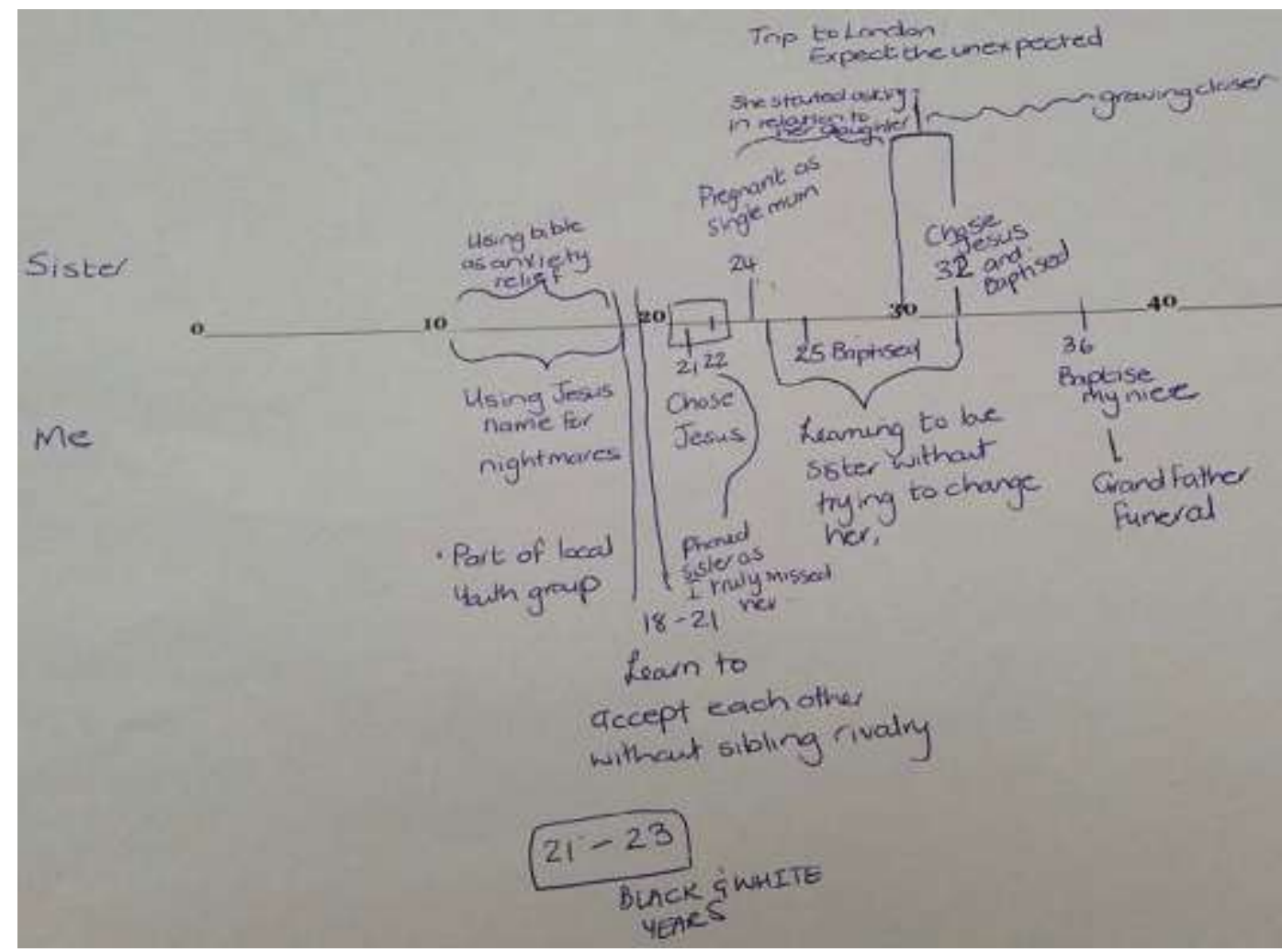

Figure 1. Jess's time-line.

ritual of baptism and a special trip to visit churches across England. Importantly, time-lines and family diagrams can also show the web of relationships in which siblings are embedded (Widmer and Jallinoja 6), for example, with aunts and nieces, who also play a part in religious lives. After the data were collected, the individual transcripts, diagrams, and timelines were read and analysed for the uniqueness of each biographical account. They were then analysed for broader sociological insights about religion in families. Patterns that emerged were religion as vicarious (Davie), as a shared inheritance, and as a source of conflict. Three 
biographical accounts that illustrate these patterns from across the data set are the stories by Margaret, Rachel, and Pippa. They show the interaction between religion and intimacy that was not linear but affected by various life circumstances in the women's lives and against a societal backdrop of religious decline and pluralism.

\section{Margaret: "Because We were Close We Could Discuss Religion"}

Margaret (age 75) and her sisters were born just before and during the Second World War and had attended church as children. She stated that they "had a very safe, happy, secure childhood" and that their grandparents influenced their Christian faith and churchgoing. As the eldest of three girls, she described a very close relationship with her middle sister, but a less close relationship with her youngest sister because of geographical distance and differences between their spouses (cf. Spitze and Trent 980). In contrast to some participants who said that faith was a contributing factor to being close, Margaret said they could discuss intimate details and questions about their faith because they were sisters: "I wouldn't say faith drew us closer together, it was something we were able to do, to discuss and ponder, because we were close." Like other women in the study, there was a specific life event that brought them closer. At the age of 48, after 30 years of marriage, the husband of Margaret's sister died suddenly of a heart attack. Margaret said that, from then on, "our friendship as opposed to just being family was totally cemented". They talked every day by phone and "knew the minutiae" of each other's lives. Following the death of her sister's husband, her sister felt that her friends could only take so much, but with Margaret she could "go over and over things and that was fine". Years later they were both diagnosed with breast cancer within three weeks of each other. After Margaret's cancer was treated, she took care of her sister up to her death. Margaret's sister, her "best friend", had died five years before the interview.

In this relationship we can see how sister relationships can encompass "elements of both family relationships and female friendship: the caring work of kinship and the apparently voluntary and chosen aspect of friendship" (Mauthner, Sistering 20). Family and friendship often blurred in the women's relationships with their sisters, equating to a closeness that could foster querying, discussion or sharing about religious practices and experiences. When talking about her sister's last moments, Margaret repeated a conversation she had had with her sister. Her sister said, "If only I could believe what you believe." And Margaret said, "Don't worry about it, I've got enough faith for both of us, and when you get there, you'll find out it was alright." In talking through Margaret's family diagram, she revealed that out of the three sisters, she was known as the 'religious one', even though they had all been raised in the Anglican Church from an early age. Because of this, Margaret was asked to convene and lead the small memorial service for her sister.

The richness and intimacy of Margaret's relationship with her sister was evident in our interview. They shared an intimacy that might not be assumed because it is usually expected that siblings grow independently of each other (Conger and Little 89), that siblings are second tier to immediate families of their own, and that widowhood is not seen to increase sibling contact (White 566). Margaret and her sister, however, provide an example of Filomeno Aguilar's (357) argument that "unity and assistance among siblings learned from youth is carried on to adult life". Religion, typically learned as a child, can contribute to the dynamics between siblings, instilling a sense of responsibility to help and support each other. Such responsibility was summed up by another participant, Gracie (age 50) who said:

In Christianity, you love your neighbour as yourself, you love your sisters and brothers, and we did that. It was a very strong influence and we'd all be there for [each other] now and that stems from our Christian upbringing.

Yet, as Britain's institutions have secularised, so have individuals and families (Bruce 3). 
Both Margaret's sisters had veered away from their Christian upbringing. Margaret's account revealed the "complex dialectic of individual autonomy and solidarity" in sibling relationships that is learned and internalised at a young age and then in adulthood is negotiated amid changing relationships to family members (Aguilar 364).

Margaret's relationship with her sister demonstrates that familial relations remain intimately interdependent and this did not necessarily cease after the sisters left the family home or chose a different religious trajectory. Rather, their close relationship enabled numerous elements of their lives, including religious aspects, to be shared and acknowledged, even if these differed. Margaret's statement about having "enough faith for the both of us", which her sister accepted, invokes Grace Davie's (22) concept of

vicarious religion ... the notion of religion performed by an active minority but on behalf of a much larger number, who (implicitly at least) not only understand, but, quite clearly, approve of what the minority is doing.

Davie (23) remarks that "churches, church leaders and churchgoers perform ritual and belief on behalf of others". This happens in the micro-processes of everyday interactions and relationships, too. Just as "churches maintain vicariously the rituals from which a larger population can draw" (ibid), ordinary individuals or 'churchgoers', such as Margaret, carry out religious practices from which others around them draw familiarity, intimacy, structure, history, and identity. Although Margaret's sister did not believe any more, Margaret's ongoing enactment of religion, being the 'religious one', kept these aspects alive for her sister and her family up to and after her death. In being asked to perform her sister's memorial service, Margaret engaged Christian symbols and rituals that are still culturally available, enabling her family to cope with their loss (Ammerman 10). Margaret's and other women's accounts demonstrates that, while they were mainly socialised into religion by their parents and grandparents, it often is or was their sibling relationships, their day-to-day connection, and closeness that enabled discussions and explorations about religion to continue.

\section{Rachel: "[Our Faith] is Part of a Shared Inheritance"}

Closeness can move sisters towards intimate religious relations and in turn religious practices and histories can contribute to and enhance a sense of closeness between sisters. Rachel (age 61) and her sisters had been brought up by their parents in the Methodist Church: "It was a big part of our lives... Even when we went on holiday, we used to go to Methodist holiday homes!" Rachel had a twin sister and an elder sister. She described her relationship with her sisters as follows: "We had each other; although we had friends, we didn't particularly have best friends beyond the family." Each of the sisters was married and had children. And although they lived in different places, they always visited each other. Rachel said that "at university and immediately post-university was when we had the least contact. I think you're just busy, aren't you, doing things which aren't family things." Once they were all married and in their "late twenties/thirties and had children, we visited each other fairly regularly... But once my Mum needed more looking after, that brought us together for a different reason." As Shawn Whiteman, Susan McHale and Anna Soli (134) note, sibling relations "are multidimensional, and vary across time and place". Rachel and her sisters were in contact and proximate to each other in numerous ways over different periods of their lives. Rachel's and other women's time-lines revealed that often the loss of a loved one could bring siblings together. In Rachel's case, after both parents had died, she and her sisters decided to make a commitment to see each other "minimal [sic] three times a year". Living in different parts of the country, they now meet and go away together for a weekend "somewhere completely random like Chester or Cardiff... We go to the cinema and theatre [together] and [we] read and pass on books to each other." When I asked Rachel about the role of religion in her and her sisters' lives, she stated that 
My elder sister, wherever she lived, she and her husband and family, just went to the local Methodist church. My twin sister, since she married quite young, 22 or 23, her and her husband have always gone to much more evangelical churches, free churches, independent ones ... whereas when we were first married we lived near Birmingham and went to the Baptist church there. We then moved up [to the North East] and the Anglican Church is about three minutes' walk from our house, so we decided that if it was ok, we would go there.

As indicated in her family diagram, Rachel and her sisters lived out different religious trajectories within Christianity, attending Anglican, Methodist, and Evangelical Churches.

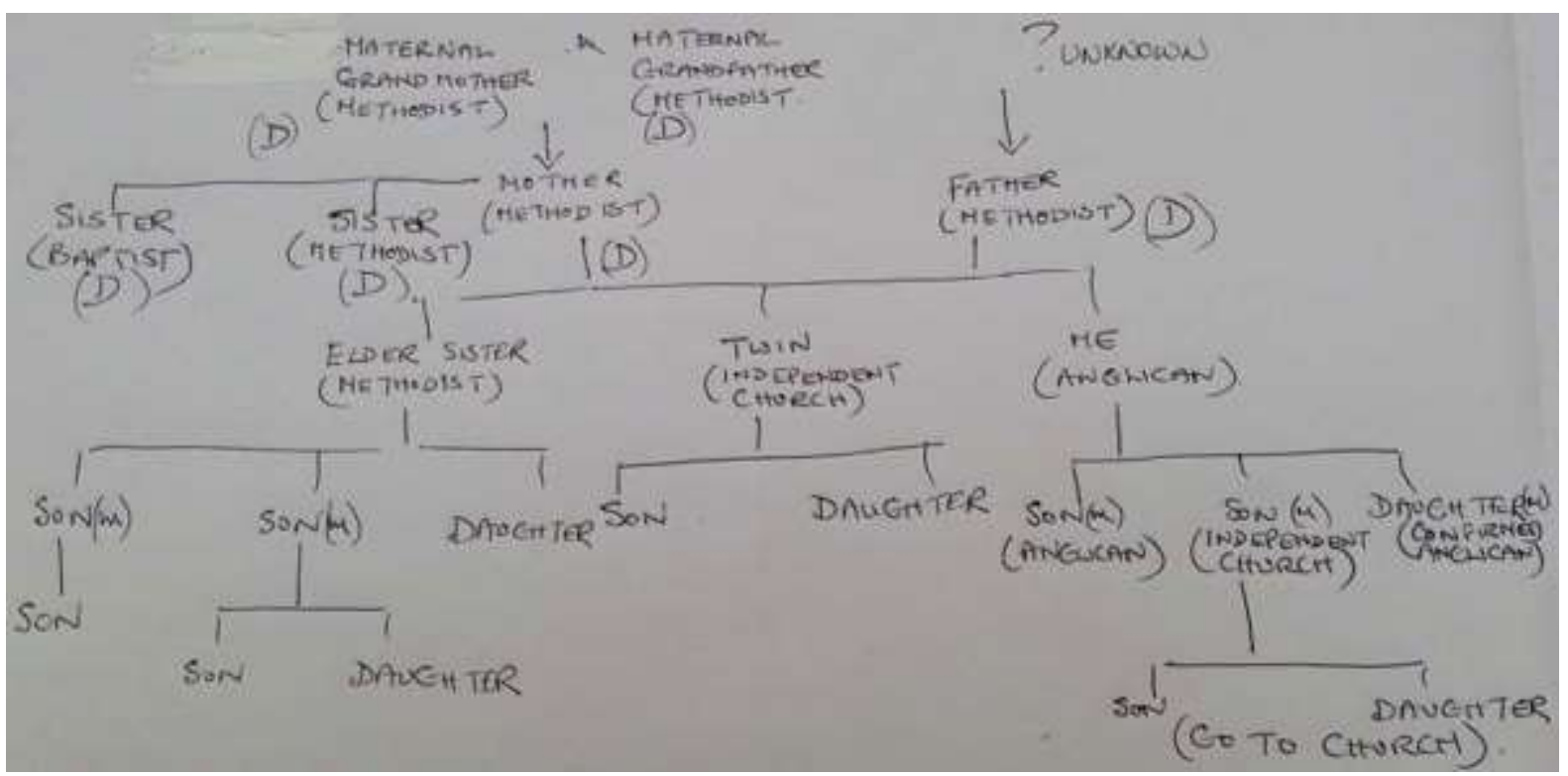

Figure 2. Rachel's family diagram ( $\mathrm{D}=\mathrm{Died} ; \mathrm{M}=$ Married $)$.

At one point in the interview Rachel described her twin sister as "a better Christian than I am" because she contrasted her twin's mission trip to Ghana with her involvement in the Mother's Union at her local church. Yet, while they preferred and attended different churches, Rachel said, “it doesn't really affect our affection for each other ... we see each other as Christians but expressing that in different ways." She then explained the role of faith for her and her sisters:

it's part of a shared inheritance... It gives us a benchmark in terms of what we expect from each other ... It gives us a language of support, a shared language means we can offer support to each other.

Following this up, I asked Rachel later in the interview what it would be like if they did not have a faith in common. She replied,

it would be part of life that wasn't shared, left at home, when we saw each other. It may have consequences on [sic] our faith, become less important, more like a hobby rather than a way of life.

Rachel explained that her sisters were important to her religious life. It was a "unifying feature" (Song 273). If she were not able to bring her religious life into their relationship, it would have implications both for her Christian faith and for their relationship with each other. Their shared inheritance might be likened to a 'template' that has the capacity to encourage, disappoint, nurture, and "reach into adult life" (Van Beekum 131). It encompasses memories, knowledge, kinship, and identity. 
Focusing on the intersection between religious practices and intimacy sheds light on the way religion takes shape and is shaped by a range of habits and activities (Bender 273). It also moves one away from "understanding religious practice as most meaningfully produced in religious settings or collectives" (ibid 284). Instead, sister relations offer another site among a broad "range of sites where we can understand the shaping of religious selves" and how social worlds shaped by lateral ties can make such selves possible (ibid 285).

\section{Pippa: "I Wouldn't Want to Alienate her because of my Faith"}

Not all sisters experienced religion as a source of closeness. In this section I present Pippa's account, where religion could be a source of identity that was negotiated in order to avoid disrupting the closeness felt with a sister who was non-religious. Mauthner (Sistering 57) discovered in her research on sisters that conflict could coincide with "aspects of power: entwined with caring responsibilities, oppressive and regulating". When religion is thrown into the mix, it can heighten these aspects. Religion and responsibility can thus intersect to facilitate intimacy and support, but also forms of self and familial governance (Oswin and Olund 60).

Pippa (age 42) was the eldest of two sisters, a mother of four children, studying to become an ordained Anglican minister. She and her sister had been brought up Catholic because of their father and attended a Catholic School. Pippa described their childhood and adolescence as very "disruptive". They moved and lived in different places and, when she was 17, her father left the family to remarry. At the time of the interview, Pippa and her immediate family were practising Anglicans and her sister was nominally Roman Catholic and married to an "ardent atheist". Their religious differences, however, were second to the importance Pippa placed on her relationship with her sister. Because their family life was unstable and they did not have extended family, Pippa said:

Because our relationship is so important ... I think it's more important than my faith position and her faith position. Our relationship, because it's constant and we have each other and there's nobody else who has our history. I think what I'm saying is that I wouldn't say anything that I thought would really upset her from my faith position. I wouldn't want to challenge her and alienate her because of my faith. We are aware that it could blow up. In families it could cause a huge amount of tension. If I started to evangelise that would be a big no, no. I just wouldn't do it.

When Pippa's sister visited her, she attended church services with Pippa and her family and any discussion about religion was led by her sister's exploration. It was clear that they had made different religious 'choices' (Song 278). In contrast to her sister's stance, Pippa's Christianity was a much stronger part of her identity, family, and social world. Yet, it was something she negotiated in relation to the secular discourses that her sister was engaged in. Song (280) notes that "perceived differences between siblings can matter a great deal in shaping family relationships". However, having different religious trajectories did not mean that Pippa and her sister were not able to support each other's different explorations of religion and secularity. It was because of their common religious histories and closeness that they were able to affirm shifts in their religious lives. The analysis of Pippa's account also revealed elements of vertical relations. As the eldest sister training to be an ordained minister, Pippa knew how her sibling and her faith position could embody parent-like aspects (cf. Ozdikmenli-Demir and Şahin-Kütük). On the one hand, examinations of religion on a horizontal axis can give a fuller picture of socio-religious worlds, on the other hand, it can conceal how some sibling relations can be parent-like, which implies a more significant power differential than other (more equitable) forms of sibling ties. In this manner, we can also observe how the horizontal and vertical intersect, rather than being diametrically 
opposed, although further research on the intersections between religion and parental and sibling relations is needed to further flesh out this contention.

Pippa's experience highlighted the tension to which John Gillis refers between the families we live 'with' (i.e. our actual family practices) and the families we live 'by', which are "the idealised version of the loving families that inhabit our cultural imaginations, notwithstanding the fact that our actual families may be unhappy, conflict-ridden places" (Smart 541). Conceptualising family and religion as interdependent, it is clear that religious tradition can play a role in (re)producing notions about family that people want to live 'by' (i.e. families being modelled on biblical narratives or 'the church family' as harmonious, loving, peaceful). The families they live by may be conjured by people in order to cope with the families they live 'with' (Sharma 817). Gillis and others contend that the traditional family ideal is an historical projection and it is rare that families are constant, safe, and secure environments. However, as Pippa's experience revealed, she attempted to hold on to elements of this ideal with her sister by not broaching contentious subjects that could potentially disrupt their close relationship. On the one hand, religion can shape the sisterly ties one lives 'by'. It contributes to an imagination of this relationship as congruous, a foundation that unites, a source of intimacy and togetherness. On the other hand, religion can be carefully handled so as not to disrupt the sister relationship one actually lives 'with'.

\section{Conclusion}

Focusing on religion and closeness between sisters brings to light a relationship that is often invisible, positioned within the realm of the private, out of the public gaze, its social significance often ignored (Mauthner, "Distant" 624, Sistering). Life between sisters is, however, diverse and rich and demonstrates another avenue by which to investigate how religion plays out in families. This research contends that, while sisters took up different approaches to religion or lived out their faith differently within the Christian tradition, their religious engagement and trajectories could be intimately linked to the lives of their siblings.

In Britain, sociologists have witnessed the secularisation of society whereby the importance of religion, particularly Christianity, has declined (Voas and Crockett; Bruce). However, examining the women's sister relationships revealed that siblings may keep religious socialisation alive. Within their families and more generally in a context of religious decline and pluralism, the women's sister ties demonstrate that religious traditions, rituals, and symbols can continue to mark people's lives, even in the lives of family members who have disaffiliated or infrequently participate (Ammerman 10). Religious traditions can endure through sibling relations and, in turn, siblings can provide support for decisions to disaffiliate or explore other forms of religion and spirituality from those prevalent during childhood.

Opposing views on religion were also present in the interviews. The effect of secularisation, as Pippa mentioned, could be felt overtly or within everyday exchanges, as Carol (age 43), another participant said, within "life as usual". Religion has the capacity to shape society, but daily habits and practices and interactions in various social spaces also have the capacity to "shape religion and religious identity" (Bender 294). The women's interviews revealed that processes of secularisation had an impact on living out religion. Yet, this did not necessarily mean a strict separation between sacred and secular, but rather intersections of religion and spirituality within intimate everyday practices and secular social worlds.

The women's accounts further exemplify Courtney Bender's (294) argument which calls attention

to the expansiveness of religious practices' contingent and complex organization within social actions and interactions, their signal ubiquity, and their ability to operate as practices do - without theorization, recognition, or trace. 
Religiosity among siblings often goes unnoted. These aspects of religion in families are not reported in surveys of religious affiliation and participation. Jonathan Scourfield et al. (92) quantitative analysis of British social surveys contends that "To understand religious change, such as secularization, one needs to consider what is happening to religious transmission", particularly "intergenerational transmission". Such analyses are helpful, but they also need to consider siblings as part of the wider network of aunts, uncles, and cousins, as, for example, explained by Jess. Lateral readings have the potential to capture 'hidden Christians' that exist within families (Guest et al. 175), those who affirm a Christian faith and spiritual practices that are not easily categorised in national surveys. Qualitative research, such as that on the women's accounts reported here, can capture how religiosity and its practices can be influenced and sustained intra-generationally through sibling ties over the life course.

Mitchell ("Siblings" 25) asks "Does the dominance of verticality hide the horizontal?" This research has begun to address the lack of research on sibling relationships within the study of religion. It has attempted to draw out the virtues of studying religion laterally, which opens up at least two areas of further investigation within the sociology of religion. Firstly, Sally Young (21) notes that it is within "sibling relationships that children practice identity" and "can learn how to be in a group". I contend that brothers and sisters have the opportunity to rehearse, perform, challenge, and question religious identities. In the women's interviews, they discussed moments when they could do this with their siblings. Explorations of religion between siblings can further expose how dynamics of religious socialisation happen within generational cohorts. Research on Christian students has shown that transmission of religious beliefs and practices between young people could be 'intragenerational', occurring in student peer living arrangements and student churches that were perceived as 'family-like' (Sharma and Guest 70, 71-2). Mitchell states that "the baby is born into a world of peers as well as of parents" (Siblings 3). The study of sisters and brothers can be a crucial starting point to lateral theorisations about the workings of religious and spiritual communities, including gender and religion.

Secondly, studies of siblings and religion could expand knowledge on health and wellbeing. Michele Dillon (12; see also Dillon and Wink 179) notes that religion and spirituality "increase in older adulthood" and "positively contribute to altruism, purposeful involvement in everyday activities and successful negotiation of the aging process". It has also been noted that sibling relationships take on stronger significance in later life. Paying attention to religion and sibling ties during late adulthood opens up opportunities to understand how these two converge to assist in what researchers know about experiences of health and aging and confronting issues of mortality and bereavement.

Morever, Dillon (7) argues that "religion is frequently forgotten or excluded from social scientific studies because it detracts from reflexivity and social change". Likewise, siblings are often ignored with the emphasis on individual trajectories. This study points to the richness of sibling relations, their collectivity, "seriality and interconnectedness" (Edwards et al. 5), and their capacity to reveal interactions between religion and social context, and to the need to expand sociological knowledge on religious (dis)continuity and transformation in families.

\section{Acknowledgements}

This work was supported by the Joseph H. Fichter Research Grant, awarded by the Association for the Sociology of Religion, USA. I am grateful to the Fichter Research Grant Committee for funding this research. I express my gratitude to the women who participated in this study and who generously allowed me to learn from them. I also express my heartfelt thanks to Christopher Harker, Dawn Llewellyn, and Jon Morgan for their comments on 
earlier versions of this work and the participants of the Theology and Religious Studies Research Seminar at the University of Chester.

\section{References}

Aguilar, Filomeno V. Jr. "Brother's Keeper? Siblingship, Overseas Migration, and

Centripetal Ethnography in a Philippine Village." Ethnography 14 (2013): 346-68.

Ammerman, Nancy T. "Introduction: Observing Modern Religious Lives." Ed. Nancy T.

Ammerman. Everyday Religion: Observing Modern Lives. Oxford: Oxford UP, 2007. 3-20.

Ammerman, Nancy, and Wade Clark Roof, eds. Work, Family, and Religion in Contemporary Society. London: Routledge, 1995.

Aune, Kristin, Sonya Sharma, and Giselle Vincett Women and Religion in the West: Challenging Secularization. Aldershot: Ashgate, 2008.

Bender, Courtney. "Practicing Religions." Ed. Robert Orsi. The Cambridge Companion to Religious Studies. Cambridge: Cambridge UP, 2012. 273-95.

Bengston, Vern L. Families and Faith: How Religion is Passed down across Generations. Oxford: Oxford UP, 2013.

Bruce, Steve. God is Dead: Secularization in the West. Oxford: Blackwell, 2002.

Cicirelli, Victor G. "Sibling Relationships in Cross-cultural Perspective." Journal of Marriage and Family 56 (1994): 7-20.

Conger, Katherine, and Wendy Jewsbury Little. "Sibling Relationships during the Transition to Adulthood." Child Development Perspectives 4 (2010): 87-94.

Connidis, Ingrid Arnet. "Negotiating Inequality among Adult Siblings: Two Case Studies." Journal of Marriage and Family 69 (2007): 482-99.

Connidis, Ingrid Arnet, and Lori D. Campbell. "Closeness, Confiding, and Contact among Siblings in Middle and Late Adulthood." Journal of Family Issues 16 (1995): 722-45.

Cornell, William F. "Lost and Found: Sibling Loss, Disconnection, Mourning, and Intimacy." Eds. Alan Frank, Patricia T. Clough, and Steven Seidman. Intimacies: A New World of Relational Life. London: Routledge, 2013. 130-45.

Crockett, Alasdair, and David Voas. "Generations of Decline: Religious Change in 20thcentury Britain.” Journal for the Scientific Study of Religion 45 (2006): 567-84.

Davie, Grace. "Vicarious Religion: A Methodological Challenge." Ed. Nancy T. Ammerman. Everyday Religion: Observing Modern Lives. Oxford: Oxford UP, 2007. 21-36.

Denton, Melinda Lundquist. "Family Structure, Family Disruption, and Profiles of Adolescent Religiosity.” Journal for the Scientific Study of Religion 51 (2012): 4264.

Dillon, Michele. "The Sociology of Religion in Late Modernity." Ed. Michele Dillon. Handbook of the Sociology of Religion. Cambridge: Cambridge UP, 2003. 3-16.

Dillon, Michele, and Paul Wink. "Religiousness and Spirituality: Trajectories and Vital Involvement in Late Adulthood." Ed. Michele Dillon. Handbook of the Sociology of Religion. Cambridge: Cambridge UP, 2003. 179-90.

Dunn, Judy. Sisters and Brothers: The Developing Child. Cambridge, MA: Harvard UP, 1985.

Ecklund, Elaine H., and Kristen L. Schultz. "Atheists and Agnostics Negotiate Religion and Family." Journal for the Scientific Study of Religion 50 (2011): 728-43.

Edgell, Penny. Religion and Family in a Changing Society. Princeton UP: Princeton, 2006.

Edwards, Rosalind, Lucy Hadfield, Helen Lucey, and Melanie Mauthner. Sibling Identity and Relationships: Sisters and Brothers. London: Routledge, 2006.

Field, Layton M. "Religious Similarity among Siblings." MA Thesis. College Station: Texas A\&M U, 2011. 
Gabb, Jacqui. Researching Intimacy in Families. Basingstoke: Palgrave Macmillan, 2010.

Giddens, Antony. The Transformation of Intimacy: Sexuality, Love and Eroticism in Modern Societies. Cambridge: Polity, 1992.

Gillis, John R. A World of Their Own Making: Myth, Ritual, and the Quest for Family Values. New York, NY: Basic Books, 1996.

Gracie. Personal Interview, October 2012.

Guest, Mathew, Kristin Aune, Sonya Sharma, and Rob Warner. Christianity and the University Experience: Understanding Student Faith. London: Bloomsbury, 2013.

Jamieson, Lynn. Intimacy: Personal Relationships in Modern Societies. Cambridge: Polity, 1998.

---. "Intimacy as a Concept: Explaining Social Change in the Context of Globalisation or another Form of Ethnocentricism?" Sociological Research Online 16.4 (2011): 1-13.

Jess. Personal Interview, May 2014.

Joseph, Suad. "Brother/Sister Relationships: Connectivity, Love, and Power in the Reproduction of Patriarchy in Lebanon.” American Ethnologist 21 (1994): 50-73.

Margaret. Personal Interview, November 2012.

Matthews, Sara H. Sisters and Brothers/Daughters and Sons: Meeting the Needs of Old Parents. Bloomington, IN: Unlimited, 2002.

Mauthner, Melanie. "Distant Lives, Still Voices: Sistering in Family Sociology." Sociology 39 (2005): 623-42.

---. Sistering: Power and Change in Female Relationships. Basingstoke: Palgrave Macmillan, 2005.

McGuire, Meredith. Lived Religion: Faith and Practice in Everyday Life. Oxford: Oxford UP, 2008.

McNamara, Jo Ann Kay. Sisters in Arms: Catholic Nuns through Two Millennia. London: Harvard UP, 1996.

Merrill, Barabara, and Linden West. Using Biographical Methods in Social Research. London: Sage, 2009.

Mitchell, Juliet. Siblings: Sex and Violence. Cambridge: Polity, 2003.

Mitchell, Juliet. "Siblings: Thinking Theory." Eds. Claudia Lament, Robert A. King, Samuel Abrams, A. Scott Dowling, and Paul M. Brinich. The Psychoanalytic Study of the Child. London: Yale UP, 2013. 14-34.

Morgan, David H. J. Family Connections: An Introduction to Family Studies. Cambridge: Polity, 1996.

---. Rethinking Family Practices. London: Palgrave Macmillan, 2011.

Office for National Statistics (ONS). Religion in England and Wales 2011. London: ONS, 2012. Available at: www.ons.gov.uk/ons/rel/census/2011-census/key-statistics-forlocal-authorities-inengland-and-wales/rpt-religion.html, access date: 9 October 2013.

Orsi, Robert. "Is the Study of Lived Religion Irrelevant to the World We Live in? Special Presidential Plenary Address, Society for the Scientific Study of Religion, Salt Lake City, 2 November 2002.” Journal for the Scientific Study of Religion 42 (2003): 16974.

Oswin, Natalie, and Eric Olund. "Governing Intimacy: Guest Editorial." Environment and Planning D: Society and Space 28 (2010): 60-7.

Ozdikmenli-Demir, Gozde, and Birsen Şahin-Kutuk. "The Role of Parents, Siblings, Peers, Relatives and Other Agents in Turkish-Muslim Emerging Adults' Religious Socializations." Archive for the Psychology of Religion 34 (2012): 363-96.

Pankhurst, Jerry G., and Sharon K. Houseknecht, eds. Family, Religion and Social Change in Diverse Societies. Oxford: Oxford UP, 2000. 
Park, Jerry Z., and Elaine Howard Ecklund. "Negotiating Continuity: Family and Religious Socialization for Second-generation Asian Americans." The Sociological Quarterly 48 (2007): 93-118.

Pippa. Personal Interview, November 2012.

Rachel. Personal Interview, October 2012.

Reed, Cheryl L. Unveiled: The Hidden Lives of Nuns. New York, NY: Berkley, 2004.

Sanders, Robert. Sibling Relationships: Theory and Issues for Practice. Basingstoke: Palgrave Macmillan, 2004.

Scourfield, Jonathan, Chris Taylor, Graham Moore, and Sophie Gilliat-Ray. "The Intergenerational Transmission of Islam in England and Wales: Evidence from the Citizenship Survey." Sociology 46 (2012): 91-108.

Sharma, Sonya. "'The Church is ... my Family': Exploring the Interrelationship between Familial and Religious Practices and Spaces." Environment and Planning A 44 (2012): 816-31.

Sharma, Sonya, and Mathew Guest. "Navigating Religion between University and Home: Christian Students' Experiences in English Universities.” Social \& Cultural Geography 14 (2013): 59-79.

Smart, Carol. "Families, Secrets and Memories." Sociology 45 (2011): 539-53.

Song, Miri. "Does 'Race' Matter? A Study of 'Mixed Race' Siblings' Identifications." The Sociological Review 58 (2001): 265-85.

Spitze, Glenna, and Katherine Trent. "Gender Differences in Adult Sibling Relations in Twochild Families." Journal of Marriage and Family 68 (2006): 977-92.

Van Beekum, Servaas. "Siblings, Aggression, and Sexuality: Adding the Lateral." Transactional Analysis Journal 39 (2009): 129-35.

Voas, David, and Alasdair Crockett. "Religion in Britain: Neither Believing nor Belonging." Sociology 39 (2005): 11-28.

Voas, David, and Ingrid Storm. "The Intergenerational Transmission of Churchgoing in England and Australia." Review of Religious Research 53 (2012): 377-95.

White, Lynn. "Sibling Relationships over the Life Course: A Panel Analysis." Journal of Marriage and Family 63 (2001): 555-68.

Whiteman, Shawn D., Susan M. McHale, and Anna Soli. "Theoretical Perspectives on Sibling Relationships." Journal of Family Theory \& Review 3 (2011): 124-39.

Widmer, Eric, and Riitta Jallinoja. Beyond the Nuclear Family: Families in a Configurational Perspective. Bern, Switzerland: Peter Lang, 2008.

Young, Sally. "The Forgotten Siblings." Australian and New Zealand Journal of Family Therapy 28 (2007): 21-27.

Yūri, Inose, and 堵瀨優理. "Influential Factors in the Intergenerational Transmission of Religion: The Case of Sōka Gakkai in Hokkaido." Japanese Journal of Religious Studies 32 (2005): 371-82.

Zhang, Qian Forrest. "The Strength of Sibling Ties: Sibling Influence on Status Attainment in a Chinese Family." Sociology 48 (2014): 75-91. 